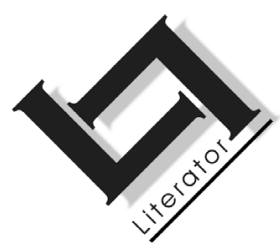

\title{
Iconicity as the key to the poetry of Nelly Sachs (1891-1970)
}

\author{
H. Ester
}

Radboud Universiteit Nijmegen,

Afdeling Algemene Cultuurwetenschappen

THE NETHERLANDS

E-mail: j.ester@let.ru.nl

\section{Abstract \\ Iconicity as the key to the poetry of Nelly Sachs (1891-1970)}

In her poetry Nelly Sachs tried to overcome all obstaclesi in order to speak about the unspeakable. Words that could adequately embody the horrors of the Nazi concentration camps were lacking. Nevertheless, it was necessary to speak about the experience for the sake of both herself and other victims of the camps. Through her poetry Sachs tests the validity and strength of both traditional images and biblical stories about suffering and grace. Words and images enable her to touch the experiences of people. However, she questions the generally accepted meaning of words in German. Her use of language strives to be different and to draw the attention to both the difficulties and risks of writing authentic words with the necessary symbolic strength. Sachs' mental fragility made her very vulnerable and caused her to walk on the edge of total silence. As a consequence of her vulnerability, she tried with her whole heart to gain Paul Celan's sympathy for her way of writing and efforts to turn the events in the concentration camps into dignified and true poetry. The relationship between Celan and Sachs reveals that the true meaning of poetry in her life was a manner of survival. The differences between the two poets provide insight into the specific poetic laws at work in the poetry of Nelly Sachs. 


\section{Opsomming}

\section{Ikonisiteit as sleutel tot die digkuns van Nelly Sachs (1891- 1970)}

In haar poësie poog Nelly Sachs om die struikelblokke in haar pad te oorkom en oor die onuitspreeklike te praat. Woorde wat na behore die gruwels van die Nazi-konsentrasiekampe kon beskryf, het nie bestaan nie. Nietemin was dit noodsaaklik om namens haarself en ander slagoffers van die kampe oor die ervaring te praat. In haar gedigte beproef Sachs die geldigheid en kragdadigheid van tradisionele beelde en bybelse verhale oor lyding en genade. Woorde en beelde stel haar in staat om mense se ervarings weer te gee. Sachs bevraagteken egter die algemeen-aanvaarde betekenis van woorde in die Duitse taal. Haar taalgebruik poog om anders te wees en die leser se aandag te vestig op die probleme en die risiko's verbonde aan die skryf van opregte, pretensielose woorde met die nodige simboliese krag. Sachs se psigiese kwesbaarheid het haar besonder broos gemaak en veroorsaak dat sy byna in totale swye verval het. Haar kwesbaarheid het ook tot gevolg gehad dat sy met haar hele hart probeer het om Paul Celan se simpatie te wen vir haar manier van skrywe en haar pogings om die gebeure in die kampe te verwoord in suiwer en waardige poësie. Die verhouding tussen Celan en Sachs toon dat poësie vir haar wesenlik 'n manier was om te oorleef. Die verskille tussen hierdie twee digters verskaf insig in die spesifieke poëtikale opvattings van Nelly Sachs se digkuns.

\section{Introduction}

This article consists of two parts. Firstly, the basic elements of Nelly Sachs' poetry are introduced, with the focus especially on the iconicity in her poetry. With iconicity is meant that the words, sentences and metaphors in Sachs' poetry are not restricted to their function as referential signs. The author's interpretation of her work is based on Juri Lotman's (1972) ideas about iconicity.

Recognising that words are referential can be regarded as the first stage of understanding by the reader. The second stage is the necessity to understand the poems by following the cues to their intrinsic characteristics. The most important characteristic of Sachs' poems is her reluctance to express definitive meanings and her endeavour to create new meanings by structuring the language of poetry towards an interdependence of poet and reader, so that this poetry is done justice only by reading it aloud. 
In the second part of the article the dynamics in the letters between Sachs and Celan is discussed. Finally, Sachs and Celan's representations of the Shoah are briefly compared. The comparison of the two kindred poets will emphasise the special qualities of Sachs' poetry, revealing her view of the German language as medium of poetry and her opinion on the importance of religion.

Everyone who reads and re-reads the work of Sachs will be deeply touched by the intrinsic strength and spiritual understanding present in her poetry, which is partly due to the frequent and incantatory use of certain words. One of those keywords is Sehnsucht (yearning). To yearn means to be filled with longing, compassion or tenderness for something. What is that "something" in Sachs' poems and plays? Bengt Holmqvist who was one of Sachs' best friends during her exile in Sweden, traces the word back to mysticism and to the mystical elements of the Chassidim (Holmqvist, 1977:44-45) The creation of the world is the manifestation of the longing of the higher spheres. The reverse implies that what has been created is longing for unity with the divine, and yearning for the restoration of that unity. An example is this poem from the volume Sternverdunklung (Eclipse of the stars, 1949) which has no title in the traditional sense.

Engel der Bittenden, nun, wo das Feuer wie ein reißendes Abendrot alles Bewohnte verbrannte zu Nacht Mauern und Geräte, den Herd und die Wiege, die alle abgefallenes Stückgut der Sehnsucht sind Sehnsucht, die fliegt im blauen Segel der Luft! $[\ldots]$

Aber immer noch spielen die Kinder im Sande, formen übend ein Neues aus der Nacht heraus denn warm sind sie noch von der Verwandlung.

Engel der Bittenden, segne den Sand, la $\beta$ inn die Sprache der Sehnsucht verstehn, daraus ein Neues wachsen will aus Kinderhand, immer ein Neues!

(Sachs, 1988:74-75; translation - HE.)

Angel of the people that ask now that the fire like an evening-glow that tears up has burnt down to night all where people lived in walls and tools, the stove and the cradle, which are all piece-goods of longing - 
longing that flies in the blue sail of the air!

$[\ldots]$

But still always children play in the sand, shape practising something new from the night

because they are still warm from the transformation.

Angel of those who ask

bless the sand,

let the sand understand the language of longing,

so that something new will grow from children's hand, always something new!

Holmqvist (1977:16) explains that Sachs' language is not only a medium of naming, of mentioning the longing. It is the language of longing and a language she creates. Her language in its efforts to express and to make words new is longing. Language is longing. Here the aspect of iconicity becomes functional.

Over the course of time, especially after her escape - together with her mother - from Berlin to Stockholm in 1940, her language becomes more and more the language of silence. On the one hand language is silence as an expression of the attempt to approach the unspeakable, and on the other hand as a test of the unspeakable. The silence between the words is iconic. This silence tells us how dubious it is to write poetry, "in spite of". The second consequence is that the words of the poem create a new meaning, a counterworld, by sustaining each other on their way to a hope beyond reality.

The main considerations for Sachs became: what could one say, and what should one say in a world where so many people were killed and in which the German language was systematically destroyed? How could all these deaths be represented by a new language?

\section{Speaking on behalf of}

Sachs escaped to Sweden before the real catastrophe, the mass murder of European Jewry, started. Her German daates from a period preceding the destruction. She found herself between the self-evident value of the language of the mystics and romantic poets like Novalis, and the deformation of the German language during the Third Reich and especially after the mass deportations. The key words used by Sachs had the power and strength to maintain their meaning. Longing and silence are the two extremes between which 
Sachs knew that she had to express herself. She did not lose her confidence in the expressive and healing power of words. For her, words could not be destroyed. Words could be abused and they had to be restored.

When considering the prospect of verbal representing the Shoah (Holocaust), the starting point of any discussion, in my opinion, should be the words of Hans Keilson in his essential essay "Wohin die Sprache nicht reicht". To where language does not stretch, does not extend, what language cannot reach, that is the fundamental notion (Keilson, 1998:40-41). No language and no linguistic conventions existed for the expression of the experiences of those who lived during the Shoah. And yet there was an overwhelming need to express, to transmitt, to pass on the experiences people had gone through. Of Celan is said that the truth comes out in the night which is paradoxically related to the phrase zutage treten and to which the expression "the truth speaks he who speaks the shadow" applies. The shadow that becomes the visible truth expresses the same paradox. Celan retreats permanently from constraining the language of his poems with convention. His poetry does not accept the comforting frame of tradition, of convention, of a coherent way of understanding. In resistance to his master Alfred Margul-Sperber, Celan shows what the limits of the use of poetic language were for him. In the overwhelming encounter with Sachs things were much more complex and it stands in contrast with his detachment from the Czernowitz poet Margul-Sperber.

Celan owed valuable connections with literary magazines to MargulSperber. For Margul-Sperber tradition was the overriding consideration and experiments were not part of this. Celan by comparison, tried to find out how far one can stretch language beyond the traditional. Sachs did the same, but from the perspective of discovering new meanings in conventional stories and words.

\section{Why can the poetry of Sachs be described as iconic?}

Nelly Sachs' poetry can be regarded as iconic for two reasons. Firstly, this poetry is iconic because it represents through its formal structure the subject and ideas it expresses. While reading her poetry the sensation is created that there is a logic beyond the logic of verbal communication. The meaning is introverted, turned inwards upon itself. It suggests a world by itself. It looks like a planet apart, but it always returns to the threshold of historical events. It touches familiar verbal expression but it never becomes identical to it. 
In Juri Lotman's words, poetic language is a secondary modelling system in which "modelling" can be understood as "producing meaning". Lotman is convinced that in poetic language the linguistic signs are iconic or perceived as iconic. In semiotics, an icon is a sign that illustrates in its material form a natural or realistic resemblance to the object to which it refers. A fundamental characteristic of iconic language is that the meaning of the words cannot be abandoned, as there is a crucial relationship between words and things. The primary code is, however, subjected to a secondary code, which produces multiple and complex meanings. The added meaning cannot be separate from the primary code. Poetic language functions as such a secondary code. Poetic language produces its own meanings. As soon as these meanings function on the level of the primary code, words are deemed to be icons. Poetry is a form of language use in which we try to escape from the disengagement or arbitrariness of the linguistic signs. Poetic language forces an iconic function upon the words we speak every day.

Lotman explains the function and the meaning of literary texts in his book Die Struktur literarischer Texte (1972), especially in chapter one and two: "Die Kunst als Sprache" and "Das Problem der Bedeutung im küntlerischen Text”. In the first chapter Lotman (1972:39) defines literature as secondary system.

Die Literatur spricht in einer besonderen Sprache, die als sekundäres System auf und über der natürlichen Sprache errichtet wird. Deshalb definiert man die Literatur als sekundäres modellbildendes System.

The linguistic signs in art do not rely on an arbitrary convention. They are iconic.

Ich habe schon bei anderer Gelegenheit ausgeführt, daß die Zeichen in der Kunst nicht auf willkürlicher Konvention beruhen, sondern iconischen, abbildenden Charakter haben. Diese These, die für die darstellenden Künste evident ist, führt bei Anwendung auf die verbalen Künste zu einer Reihe wichtiger Schlußfolgerungen. Iconische Zeichen sind nach dem Prinzip einer immanenten Kopplung von Ausdruck und Inhalt konstruiert. (Lotman, 1972:40.)

At another occasion I have explained that the signs in art do not rely on arbitrary convention, but that they have iconic, depicting, picturing character. This thesis is evident for the performing arts and leads in its application to the verbal arts to a number of important conclusions. Iconic signs are constructed on the basic 
principle of an immanent combination of expression and meaning.

Within a linguistic paradigm the verbal arts will make a syntagmatic choice, based on the principle of equivalence (Lotman, 1972:58, 76).

Through her poetry Sachs endeavours to name things one cannot name or mention. In her poetry the arbitrary character of words is transformed into a unity beyond an order to ease a person's mind, to comfort somebody. In her poetry there is an order in disorder, or put differently, the poems keep the awareness, the consciousness of disorder parallel to the appearance of order. Her iconicity is a unity of signals. These signals instruct the reader to tread very cautiously within this poetic space.

This observation leads to the second element of iconicity in Sachs' work. What is said, is said with reservation. In line with Jacques Derrida one observes that these poems carry elements of far-reaching deconstruction as well as prudent, risky construction in themselves. They represent the impossibility to refer and at the same time the need to give an iconic charge to words, so that they can refer without the conventional reality of referring. What is essential in this poetry? Where are the boundaries of what they try to evoke as opposing forces? Sachs asks herself: why am I writing my text in this way? Sachs is at the same time both author and reader of her poems.

Longing is the element that exceeds the limits of expression and the practice of self-observation. The final impulse to write is the poet's hope that, against all doubts and against all internal disassembling, this poetry will construct a new basis of exchange, a constructive form of dialogue. What finally comes to the surface is a surprising experience, the experience that something speaks that does not want to be controlled entirely. This "something" breaks through the barriers and creates iconic signs of sincerity. A new name, that is Sachs' basic longing, and a new name is a new way of being named.

The new name would be the consequence of her new language, a confirmation of a suffering that leads to blessing. The language cannot reach the unspeakable essence of the experiences, but it can create an iconic quality of its own. The new name is the result of an injury. The reference to Jacob's struggle with the angel is the intertext. Just like Jacob, the voice in the poem says: I will not let you go, unless you bless me. Blessing in these poems is the strength, the 
knowledge, the certainty of another step - not more than one step and not less than that limited movement.

\section{Strain, longing, Jacob, Israel}

In her efforts to save the German language and to keep it warm, Sachs had to leave a vacuum of withdrawal from the present time. The main feature of her present time was the mass killing of European Jewry. What could have been the answer to that culture of destruction? It could have been silence, definite silence. It could also have been disregard. But neither was an acceptable option. For Sachs there was only one option, an option that included development and creativity in the realm of honesty. Sachs chose (or was led to) a form of continuity of language in which she had to account for the destruction of the people with whom she had a relationship of fate, a common fate. She chose words to represent under reservation, conditionally, the things that had happened and that were happening. The creative use of preformed language, which covered the recent history of her lifetime under a layer of convention, made her work vulnerable. The vulnerability lies in the incongruity between event and verbal, poetic representation.

At this point the word strain is important. Strain (Verrenkung) is understood as a force that tests cohesion or stability, and it includes injury resulting from such exertion. Here lies the critical effort of Sachs. Strain is combined with longing - it is a longing for God or for the awareness of God. Mankind is condemned to being injured. It is the story of Jacob wrestling with the angel, Jacob whose hip was injured, a story to which Nelly Sachs refers. Jacob's new name is Israel. Mankind is condemned to be handicapped, to bodily infirmity. Is it human fate to stumble and stagger through the world? There is more than this. Sachs maintains in her perception of mankind's suffering the unity with creation as a whole. She feels responsible for answering the needs of the present time, and at the same time she frames the utterance with her idea of a cosmic transformation.

This, however, does not lead to a thesis, to a firm stand against superficiality on the one hand, and despair on the other - the latter possibly being in combination with silence. It is a direction of thinking rather than a completed programme. In the following poem the word chiffre appears. Chiffre means that symbolic meaning replaces referential meaning. The chiffre as a linguistic sign reduces the easy way of understanding and requires the repetition of hermeneutical understanding on the level of reading inversely. Sachs feels the events taking place in the concentration camps. She looks for the 
moments of transformation of her overwhelming feelings. How credible are these moments, if they are to represent the factual atrocities against people? The wound, the injury is our dwelling-place, our residence. Is it conceivable that this is a locality of grace? Can an injury, like Jacob's, be a form of grace?

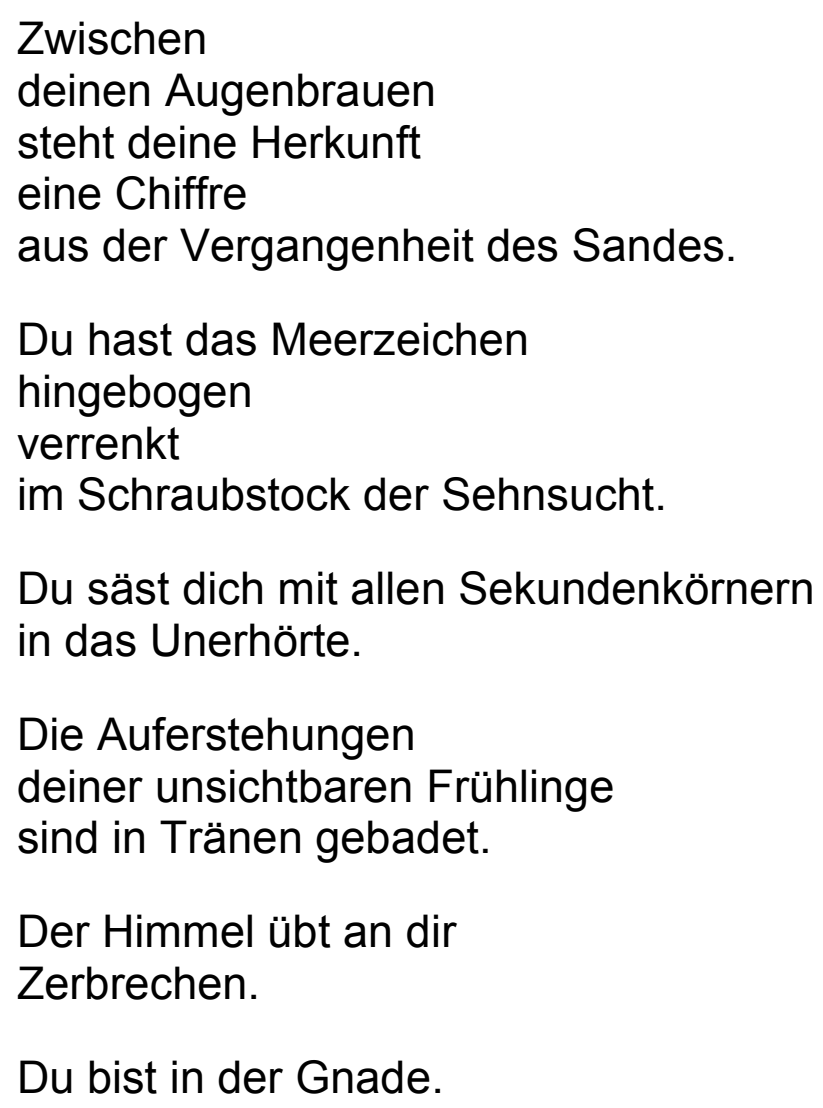

Der Himmel übt an dir Zerbrechen.

Du bist in der Gnade.

(Sachs, 1988:267; translation - HE.)

\section{Between}

your eyebrows

stands your origin

a cipher

from the forgetfulness of the sand.

You have

bent

injured

the sign of the sea

in the thumbscrew of longing.

You sow yourself with all the grains of the seconds into the unheard of.

The resurrections

of your invisible springs

are bathed in tears. 
Heaven practises on you

falling to pieces.

You are in a state of grace.

\section{The keywords}

During her years in Sweden Sachs read a lot. Her only aim was to find a meaning for her individual suffering, the problems inherent to the life of mankind, and for the suffering creatures of the entire creation. The central position of longing is strongly tied to fear and doubt, rather than to confidence and certainty. Sand is an essential part of her poetry as it is of the plays (Mysterienspiele) Sachs wrote. The sand evokes the history of the Jewish people without explaining the reference. The word grain is related to it. The above quoted poem touches very cautiously on the dream of the living desert and suggests the sphere of religion by using the word grace.

If we talk about her identity, it is very clearly that Sachs' Judentum, her being Jewish, was absolutely indispensable to her. Being Jewish for Sachs had the same meaning as suffering. Her personal pain and sorrow were part of a coherent totality, the totality of suffering and longing.

The following quote comes from the best known poem by Sachs from the collection of poems, In den Wohnungen des Todes (In the dwellings of death, 1947). The motto of the poem is from Job 19:26.

Und wenn diese meine Haut zerschlagen sein wird, so werde ich ohne mein Fleisch Gott schauen

In the King James version this motto reads:

And though after my skin

Worms destroy this body,

Yet in my flesh

Shall I see God.

Sachs, however, quotes "I shall see God without my flesh". In the revised edition of the Bible (1948), translated by Martin Luther, the text from Job is almost identical to Sachs' quotation. But the comment says that Luther originally translated "in my flesh". We find this wording in most modern translations of the Bible. The conclusion must be that there is not only a great amount of interpretation by Sachs in her choice of the quotation from Job, but that her 
preference of "without" instead of "in" has a meaning that is fundamental for her human involvement.

O die Schornsteine

Auf den sinnreich erdachten Wohnungen des Todes,

Als Israels Leib zog aufgelöst in Rauch

Durch die Luft -

Als Essenkehrer inn ein Stern empfing

Der schwarz wurde

Oder war es ein Sonnenstrahl?

O die Schornsteine!

Freiheitswege für Jeremias und Hiobs Staub -

Wer erdachte euch und baute Stein auf Stein

Den Weg für Flüchtlinge aus Rauch?

O die Wohnungen des Todes,

Einladend hergerichtet

Für den Wirt des Hauses, der sonst Gast war -

$\mathrm{O}$ ihr Finger,

Die Eingangsschwelle legend

Wie ein Messer zwischen Leben und Tod -

O ihr Schornsteine,

$O$ inr Finger,

Und Israels Leib im Rauch durch die Luft!

(Sachs, 1988:8; translation - HE.)

Oh, the chimneys

On the ingenious dwellings of death,

When Israel's dissolved body

Drew through the air -

As a chimneysweeper a star welcomed him

That became black

Or was it a sunbeam?

Oh the chimneys

Roads of liberty for the dust of Jeremiah and JobWho invented you and built brick by brick

The road for refugees of smoke?

Oh, the dwellings of death,

Constructed invitingly

For the host of the house, who used to be guest Oh, you fingers,

Laying the threshold of entrance

Like a knife between life and death - 
Oh, you chimneys,

Oh you fingers

And Israel's body in smoke through the air.

The commandant of the concentration camp, the hangman, side by side with the victim - this is a tempting, provocative way of staging. But Sachs does not suggest that there is an excuse for the hangman, the executioner. Instead she pleads for something else, she pleads for mourning. The words chimneys, brick, threshold, dwellings and host are essential in this poem, as a distressing comparison between a stable home with a road and smoke rising into the air.

The second volume of poems, Sternverdunkelung (1949), is much more pessimistic, as it lacks answers compared to the previous collection. In the middle of the fifties of the last century, we observe a new lyrical break-through by Nelly Sachs: Und niemand weiß weiter (Nobody knows how to go on any further 1957) and Flucht und Verwandlung (Escape and transformation, 1959). New is the keywords, the "royal" words, as Holmqvist puts it: Flight or escape. Being on the run, to flee, is a situation of longing. The next collection to be published by Sachs (1964) is Glühende Rätsel (Glowing mysteries, 1964).

At this stage we can list the keywords in the poetry of Sachs: longing, flight, death, sand, grain, children, chimneys, transformation, love and longing (again, because of its importance). Longing seeks out words as provisional resting places, as outlines of the unity with the world, in the world, and with the world beyond this world. Fracture and challenge appear with the evil intentions of a political ideology to destroy the words, intentions that can build a world of hostility and can exceed what the human mind can comprehend. The challenge leads to a relationship between longing, escape, death and transformation. Sachs' summary of the Psalms, the prophets, and of the Scriptures she came to know via Martin Buber (like the Sohar), account for images that form an integral part of her fractions - fractions that can always transform into fractures and vice versa. In no way a systematic unity comes to existence. These images orbit around the words as their secret centres.

\section{Paul Celan}

In her volume Sternverdunkelung Sachs calls Israel "The wound created by God" or "The wound of God" (Gotteswunde), and in its 
behaviour the most reckless under the sleepwalkers. What will Celan have thought of such a risky way of expression?

Paul Celan was the ultimate critic of Nelly Sachs' words, he became the living standard by which her work was appraised. His language was iconic for Sachs for two reasons.

Firstly, he was her closest companion, as they had similar ways of observing words, and shared a suspicion towards the signs of language and referential words. Secondly, he was also the creator of her new name, the name she was looking and longing for. A name is not arbitrary and cannot be replaced unless a new name has added iconic value. Sachs begged Celan for this new name - comparable with how Jacob became Israel. Celan had to confirm who she was in the province of her poetry.

Sachs has never been popular. The number of readers of her poems has never been comparable with the readers of Celan's poetry. Friends of Sachs have promoted her work and a sign of an impending change is the publication of a volume containing a comprehensive study of various aspects of her work: Nelly Sachs: éthique et modernité (Lerousseau et al., 2007). Particularly the contributions by Blandine Chapuis, Vivian Liska and Bernard Böschenstein create an fresh approach to her work. In her essay "La voix d'Israël: prosopopée et signe messianique dans les 'Chœrs d'après minuit' de Nelly Sachs", Liska clearly perceives that the "living contrast" between Celan and Sachs is based on Celan's rejection of what he supposes to be Sachs' idea of reconciliation and Verklärung. Liska clearly sees the encounters in the works of both poets regarding the treatment of words as signs (Liska, 2007:115). In Liska's view this is a distinctive quality of all Sachs' poetry. This analysis comes very close to what the author of this article see as the key to Sachs' poetry: meaning comes into being from the similarity between a representative sign and what what it represents.

Le recueil de poèmes de 1946, In den Wohnungen des Todes (Dans les demeures de la mort), est placé sous le signe d'une tension entre restauration et résignation, pardon et impossibilité de réconciliation, revivification poétique en deuil traumatique d'une perte irréparable contrebalancé, il est vrai, par des manifestations d'espoir messianique. Dans cette tension, l'intrication de la voix et de la trace, de l'évocation immédiate d'une présence et du signe qui renvoie à un référent absent, joue un rôle particulier. On y perçoit clairement comment Nelly Sachs reprend à la fois les conceptions du romantisme et dans 
une certaine mesure les remet en question face au deuil ressenti envers ceux qui furent assassinés. (Liska, 2007:115.)

The collection of poems of 1946, "In the dwellings of death", is placed under the sign of tension between restoring and resignation, between forgiving and the impossibility of reconciliation, poetical regeneration and traumatic mourning over an irreparable loss, counterbalanced, I admit, by manifestations of messianic hope. Within that tension the intricateness of the voice and the trace, of the immediate evocation of a presence and of a sign which refers to an absent referent, play a notable role. The observer perceives very clearly how Nelly Sachs recaptures the concepts of romanticism and to a certain degree at the same time brings them up for discussion in the confrontation with the deeply felt grief towards those who were assassinated.

Böschenstein (2007) surprises with his contribution on "Le regard de Paul Celan sur Nelly Sachs et les choix de Hans Magnus Enzensberger en de Hilde Domin". Sachs was awarded the Nobel Prize for literature on 10 December 1966. On that night Celan read 25 of her poems. Böschenstein shows how significant this choice was, as itreflected Celan's way of seeing her and his poetry.

Il est important de voir que Celan s'arrête à ce seuil et atteste la légitimité d'un état vers lequel tend toute l'œuvre poétique de Nelly Sachs. Il se solidarise avec cette conception utopique de la poésie qui est toujours en route et qui veut aller vers un Autre. Die Suchende rejoint ainsi l'éssentielle du Méridien de Paul Celan, peu de temps après sa création. Les six vers choisis par Celan dans ce cycle qui ne comprend que quatre pages ont ainsi valeur de testament. (Böschenstein, 2007:145.)

It is important to see how Celan reaches for this threshold [of a posthumous word] and certifies the legitimacy of a mental constitution towards which the whole poetical oeuvre of Nelly Sachs tends. He associates himself with that utopian concept of poetry which is always on the road, always en route and which wants to go in the direction of an Other. The poem "Die Suchende" brings together again, reunifies in this way the essential truth of the "Méridien" by Paul Celan, shortly after the creation of this poem. The six verses that were chosen by Celan within these series comprise only four pages and thus have the value of a last will and testament.

However, this form of solidarity is a fact that we put on record now the result of critical analysis. Yet, this is certainly not the dominant theme in their correspondence. 
The letters between Sachs and Celan are the documents of a meeting between two kindred spirits, the difference between their approaches to the Shoah, however, was a major obstacle in their relationship.

When did their correspondence start? The first letter is one from Sachs to Celan in 1954 in which she thanks him for sending her a volume of poems, Mohn und Gedächtnis. The end of the letter provides an indication of the common position she was looking for.

Auch ich muss diesen inneren Weg gehn der von 'Hier' ausgeht nach dem unerhörten Leiden meines Volkes, und der weitertastet aus der Qual. (Celan \& Sachs, 1996:9.)

I also must follow this internal way that leads from 'Here' to the unheard-of sufferings of my people, and that gropes from the distress.

The last words can also be translated by and goes on touching from the misery. The way that Celan addressed Sachs is much more formal than her call for togetherness. While she writes "Lieber, so verehrter Dichter Paul Celan" (Dear, much honoured poet Paul Celan), he keeps on writing "Sehr verehrte gnädige Frau" (Most honourable madam), with a certain Austrian strain. In 1957 Sachs reacts to a letter by Celan and writes: "Sie wissen um meine Dinge, haben sie bei sich, so habe ich Heimat" (You know my essential feelings, you carry them with you and therefore I have a place to live) (Celan \& Sachs, 1996:10). Thus, I am at home. Could Celan deny her this home? She defines her poems as ways to save breath so that she doesn't suffocate. In 1958 she asks Celan: "Please, call me by my name." (Celan \& Sachs, 1996:12.) In the same letter from January 1958 she reveals the fundamental contents of her being.

Es gibt und gab und ist mit jedem Atemzug in mir der Glaube an die Durchschmerzung, an die Durchseelung des Staubes als an eine Tätigkeit wozu wir angetreten. Ich glaube an ein unsichtbares Universum darin wir unser dunkel Vollbrachtes einzeichnen. Ich spüre die Energie des Lichtes die den Stein in Musik aufbrechen läßt, und ich leide an der Pfeilspitze der Sehnsucht die uns von Anbeginn zu Tode trifft und die uns stößt, außerhalb zu suchen, dort wo die Unsicherheit zu sp̈len beginnt. Vom eignen Volk kam mir die chassidische Mystik zu Hilfe, die eng im Zusammenhang mit aller Mystik sich ihren Wohnort weit fort von allen Dogmen und Institutionen immer aufs neue in Geburtswehen schaffen muß. (Celan \& Sachs, 1996:13; translation - HE.) 
With every breath in me is the faith in the 'Durchschmerzung des Staubes', dust that is spread through with sorrow, dust that is saturated with soul. This faith is an activity to which we are called. I believe in the invisible universe in which we engrave our obscure achievements. I feel the energy of the light that breaks the stone into music. And I suffer from the sharp arrow of longing which touches us to death from the beginning, which pushes us to look somewhere beyond, where the uncertainty washes ashore. From my own people the 'chassidische Mystik' helped me, which, in combination with all mysticisms has to create its dwelling in violent pangs of birth far from all institutions and dogmas.

Essential to this correspondence is the incongruity in quantity, direction and creed. Celan addresses Sachs in superlatives, but his superlatives are not balanced by the contents of his letters. Sachs' letters are incantations. The repetition of Celans first name and the repetition of the personal pronoun bear the ultimate meaning of Sachs' words. Both the words and the form of these letters are representative of Sachs' fragility as well as her hazardous undertaking to link her own vulnerability with the endangered existence of another human being. In 1959 Sachs wrote: "dear Paul Celan, from now on we shall convey the truth to each other". In May 1960 she wrote:

Dear Paul, I would have preferred to close my eyes forever after the last experiences. The lonely one and the sleeping disciples - eternal image. When we suffer, we only still belong to God - that is why our friends leave us. Be comforted. You keep the balance. (Celan \& Sachs, 1996:38-39.)

The letters Sachs writes to Celan come very close to her poems communicating in one way aims at recognition in the other, more fundamental way.

Were they talking about the same balance? Was it not a risk to refer to Jesus and his followers, as Sachs did in her letter from May 1960 ? In that same month, Sachs and Paul meet each other. Celan writes a letter to Sachs in the form of a poem:

Zürich, Zum Storchen

(Für Nelly Sachs)

Vom Zuviel war die Rede, vom

Zuwenig. Vom Du

und Aber-Du, von

der Trübung durch Helles, von 
Jüdischem, von

deinem Gott.

Da-

von.

Am Tag einer Himmelfahrt, das

Münster stand drüben, es kam

mit einigem Gold übers Wasser.

Von deinem Gott war die Rede, ich sprach

gegen ihn, ich

lie $\beta$ das Herz, das ich hatte,

hoffen:

auf

sein höchstes, umröcheltes, sein

haderndes Wort -

Dein Aug sah mir zu, sah hinweg,

dein Mund

sprach sich dem Aug zu, ich hörte:

"Wir

wissen ja nicht, weißt du,

wir

wissen ja nicht

was

gilt ..."

(Celan \& Sachs, 1996:41-42; translation - HE).

Zürich, [Hotel] Zum Storchen

(For Nelly Sachs)

There was talk about too much, about

too little, About you

and you again, about

darkening by brightness, about

Jewish affairs, about

your God.

About

that

On the day of an Ascension

the Dome stood beyond,

it came with some gold across the water.

There was talk about your God, I spoke

against him, I

let the heart that I had

hope 
for

his highest, rattling, his

disputing word. -

Your eye was looking at me, looked away,

your mouth

spoke towards the eye, I heard:

"We

do not know, you know,

for we, we do not know

what

counts ..."

In July 1960 Nelly Sachs fell very ill. Her mind was filled with the obsession that Neo-Nazis tried to kill her. She was troubled by the idea of attacks, as was Celan. One wonders, if the meeting in Zurich, and later in Paris, contributed to Sachs' mental state. At any rate, it is clear that Celan had contributed to her inner unrest by a suggestion in another letter (from which we only have a rough copy, the actual letter was burnt) that an author like Alfred Andersch was after him. After October 1960 it took Celan three months to answer her repeated letters. On 5 December Sachs even wrote to the Celan family: "Paul, you, dear brother, and my dearest entire family Celan, I have been waiting so long for news - but I may have hurt you, at the time of my desperation". Paul Celan's answer tries to turn the theme of their correspondence to practical subjects. An element of soberness has taken over in his letters. Jean Bollack writes about the relationship between Celan and Sachs in his profound book Dichtung wider Dichtung: Paul Celan und die Literatur. In the second part of this book with the subtitle "The contradiction", Bollack (2006: 81) attempts to explain in a chapter entitled "Nelly Sachs" why things went wrong between the two poets:

Man sollte nicht unterschätzen, wie verschieden der kulturelle Horizont und das Maß an Freiheit inm gegenüber bei diesen beiden Dichtern war, die beide groß waren, beide Juden und beide durch die Negation der deutschen Sprache gegangen sind.

We should not underestimate how different the cultural horizon and the degree of freedom towards this horizon was for each of these poets. They were both great poets, they were both Jews and they both had gone through the negation of the German language. 
Concentrating on the different role of God in their work, especially their letters, Bollack (2006:81) writes:

Die Briefe sind nicht leicht zu lesen oder zu deuten. Trotz des Grundtons von Solidarität und Wärme haben sie etwas Gequältes. Nelly ist die 'Schwester' im biblischen Sinne, die jüdische Dichterin, die in ihrer Dichtung die Greuel der Lager verewigt. Aber die Standpunkte sind darob nicht weniger radikal entgegengesetzt. Der eine hat sich auf die Seite der menschlichen Vergeltung gestellt, Auge um Auge, ohne Versöhnung, und fordert von jedem, sein eigener Gott zu sein. Die andere hat einen Gott der Liebe gewählt, der niemandem gehört; sie lehnt die Rache ab und sagt dies ständig und nachdrücklich. Sie will Celan retten, auch gegen sich selbst.

The letters can not easily be read or explained. In spite of the prevailing tone of solidarity and warmth the letters have something overstrained. Nelly is the 'sister' in the biblical sense, the Jewish poetess who immortalizes in her poetry the horrors of the concentration camps. The positions and attitudes, however, are incompatible with regard to these horrors. The one has chosen the side of human retaliation, an eye for an eye and a tooth for a tooth, without reconciliation. He requires from everybody to be one's own god. The other one has chosen a god of love, a god that belongs to nobody. She rejects revenge and tells this continuously and emphatically. She wants to save Celan, even against his own will and convictions.

But this way of describing the complexity of their overtaxed communication is very unsatisfactory. Bollack locates the source of their disagreement in their diverging perceptions of language, poetry and faith. The weak point of Bollack's way of reasoning lies in his superficial classification of the poetry written by Sachs. He does not understand that Sachs never comes to an ultimate conclusion in the sense of reconciliation or religious faith. Her poetry always bears a question mark. Questioning is part of her language, her iconic language. Seen from Bollack's identification with Celan, his judgement of Sachs does not fully represent the meaning of her work (Bollack, 2006:76, 81, 92).

From 1961 until 1963 Sachs was in hospital again. In a poem for her brother Paul Celan she wrote the lines:

Bromma, d. 3. 9. 1961

Beckomberga Sjukhus 
Wer ruft?

Die eigene Stimme!

Wer antwortet?

Tod!

Geht die Freundschaft unter

im Heerlager des Schlafes?

Ja!

Warum kräht kein Hahn?

Er wartet bis der Rosmarinkuß

auf dem Wasser schwimmt!

Was ist das?

Der Augenblick Verlassenheit

aus dem die Zeit fortfiel

getötet von Ewigkeit -

Was ist das?

Schlaf und Sterben sind eigenschaftslos.

(Celan \& Sachs, 1996:78-79; translation - HE.)

Bromma, 3 September 1961

Beckomberga Sjukhus

Who calls?

The own voice!

Who answers?

Death!

Does friendship perish

in the army-camp of sleep?

Yes!

Why does the cock not crow?

He waits till the kiss of rosemary

floats on the water!

What does that mean?

The moment of desolation

from which time fell away

killed by eternity -

What does that mean?

Sleep and dying have no qualities. 


\section{The desire to be confirmed}

The letters and poems Sachs sends to Paris are loaded with the desire to be confirmed in the value of her approach as a poet. Sachs longs for the Celans and sends them her blessings. In her letters she is not troubled by hesitation to express her religious longing. She sends them her blessings for the year 1966 and accompanies her good wishes with a poem from which the last verses are:

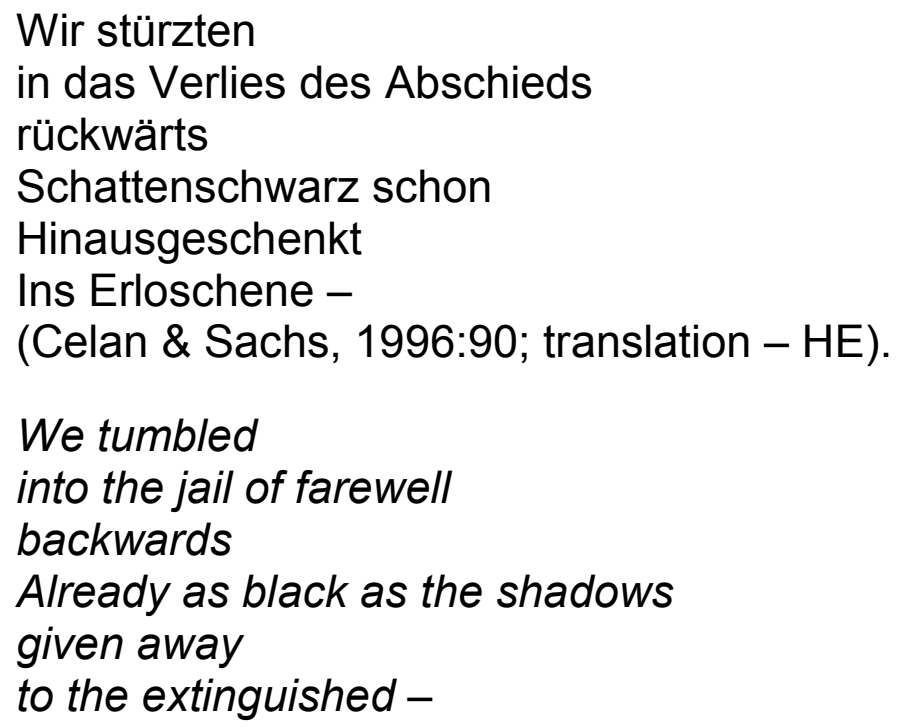

The year 1966 was an important year as far as the public recognition of Sachs is concerned. She received the Nobel Prize for literature, together with the Israeli author Joseph Agnon. Paul Celan was invited to take part in the ceremony in Stockholm, but he wrote to Sachs that a trip to Stockholm was not possible because of his work at the École normale in Paris. Doubtless this must have been a disappointment for Sachs. After 1966 their correspondence was never as intense as before.

In 1968 the period of brightness ended again for Sachs. In one of her last letters, dated 10 February 1969, Sachs mentioned the common centre for her and Celan:

I came home and wrote the lines I send you. Home, you will understand, in the invisible home country we both live. Your poems within the range of my hand. During the evening before going to sleep I read, that is how we pray. (Celan \& Sachs, 1996:103-104.)

This correspondence fades out gradually until Sachs' last lines at the end of 1969: "Paul, You dear friend, you, many best wishes. All your poems are with me in this time of suffering." (Celan \& Sachs, 1996:106.) Nelly Sachs passed away on 12 May 1970, the same 
day Celan was buried after he made an end to his life on 20 April 1970.

As I already explained, in the overwhelming encounter with Nelly Sachs the search for representation and articulation was much more difficult than in Celan's distance towards the Czernowitz poet Margul-Sperber. Because here the starting-point was the same - Sachs was very, very familiar, in her suffering and in her poetic expression. The enormous emotional pressure that Sachs put on Celan was aimed at getting him to accept her cry of distress.

Finally, this was unacceptable to Celan. Sachs kept an untouched faith in the iconic quality of words and in the mystic approach to the world, to mankind and to the transcendental. Her being was threatened too, but she kept returning to the edge of covering emotions and words. In this Celan could not follow her, and Sachs could not return to a stage she had left in order to survive.

\section{List of references}

BOLLACK, J. 2006. Dichtung wider Dichtung: Paul Celan und die Literatur. Göttingen: Wallstein Verlag.

BÖSCHENSTEIN, B. 2007. Le regard de Paul Celan sur Nelly Sachs et les choix de Hans Magnus Enzensberger en de Hilde Domin. (In Lerousseau, A., Cazalé-Bérard, C. \& Combes, A., eds. Nelly Sachs: éthique et modernité. Actes du Colloque International, Maison de la Recherche de l'Université Charles-de-Gaulle, Lille 3, 26 et 27 novembre 2003. p. 137145.)

CELAN, P. \& SACHS, N. 1996. Briefwechsel. Frankfurt am Main: Suhrkamp Verlag. (Suhrkamp Taschenbuch, 2489.)

HOLMQVIST, B. 1977. Die Sprache der Sehnsucht. (In Sachs, N., Das Buch der Nelly Sachs. Frankfurt am Main: Suhrkamp Verlag. S. 9-70.) (Suhrkamp Taschenbuch, 398.)

KEILSON, H. 1998. Wohin die Sprache nicht reicht. (In Keilson, H. Wohin die Sprache nicht reicht. Essays - Vorträge - Aufsätze 1936-1996. Gießen: Ricker'sche Universitäts-Buchhandlung. S. 37-49.)

LISKA, V. 2007. La voix d'Israël: prosopopée et signe messianique dans les "Chœrs d'après minuit" de Nelly Sachs. (In Lerousseau, A., CazaléBérard, C. \& Combes, A., eds. Nelly Sachs: éthique et modernité. Actes du Colloque International, Maison de la Recherche de l'Université Charles-de-Gaulle, Lille 3, 26 et 27 novembre 2003. p. 111-123.)

LOTMAN, J. 1972. Die Struktur literarischer Texte. München: Wilhelm Fink Verlag. (Uni-Taschenbücher, 103.)

SACHS, N. 1947. In den Wohnungen des Todes. Berlin: Aufbau-Verlag.

SACHS, N. 1949. Sternverdunkelung. Amsterdam: Bermann Fischer.

SACHS, N. 1959. Flucht und Verwandlung: Gedichte. Stuttgart: Deutsche Verlags-Anstalt.

SACHS, N. 1964. Glühende Rätsel. Teil 1 \& 2. Frankfurt am Main: Insel Verlag. 
SACHS, N. 1977. Das Buch der Nelly Sachs. Frankfurt am Main: Suhrkamp Verlag. (Suhrkamp Taschenbuch, 398.)

SACHS, N. 1988. Fahrt ins Staublose: Gedichte. Frankfurt am Main: Suhrkamp Verlag. (Suhrkamp Taschenbuch, 1485.)

\section{Key concepts:}

Celan, Paul

European history

iconicity

Jewry

religion

shoah/holocaust

Kernbegrippe:

Celan, Paul

Europese geskiedenis

godsdiens

ikonisiteit

Jodendom

shoah/holocaust 
